\title{
ILOŚCIOWE LUZOWANIE POLITYKI PIENIĘŻNEJ NA PRZYKKADZIE FED - ISTOTA, CELE I SKUTKI
}

Słowa kluczowe: ilościowe luzowanie, kryzys, polityka pieniężna.

Abstrakt: W reakcji na kryzys Rezerwa Federalna przeprowadziła operację ilościowego luzowania w celu wsparcia gospodarki narodowej. W pracy zbadano skuteczność ekspansywnej polityki pieniężnej realizowanej przez Fed. Stwierdzono niewielkie efekty gospodarcze takich działań oraz poważne zagrożenie inflacją.

\section{QUANTITATIVE EASING - IDEA, TARGETS AND RESULTS}

Keywords: crisis, monetary policy, quantitative easing.

Abstract: In reaction for a crisis Fed implemented quantitative easing to stimulate national economy. In this paper there were searched the efficiency of expansionary monetary policy used by central bank. It was stated slight economic results of those actions and seriously threat of inflation.

Translated by Dariusz Piotrowski

\section{WsTĘP}

Kryzys gospodarczy i finansowy, który odczuwają od kilku lat miliony osób, tysiące firm i dziesiątki krajów, jest zjawiskiem rzadko obserwowanym. Z racji

Data wpłynięcia: 22.11.2012; data zaakceptowania: 25.02.2013.

* Dane kontaktowe: darius@econ.uni.torun.pl, aniap@doktorant.umk.pl, Katedra Zarządzania Finansami, Wydział Nauk Ekonomicznych i Zarządzania, Uniwersytet Mikołaja Kopernika, ul. Gagarina 13a, 87-100 Toruń, tel. 566114634. 
skali i intensywności oddziaływania na różne aspekty życia ludności i funkcjonowania przedsiębiorstw oraz państw jest porównywany do okresu wielkiej depresji z lat 1929-1933. Kryzys spowodował wzrost bezrobocia, spadek dynamiki PKB, a nawet wejście $\mathrm{w}$ fazę recesji wielu gospodarek. W wyniku kryzysu upadło wiele firm, w tym również banków. Kryzys wpłynął nie tylko na notowania instrumentów finansowych i ceny surowców. Wymusił także zmiany w sferze ekonomicznej, społecznej czy naukowej. Podał w wątpliwość wiele głoszonych teorii oraz podważył słuszność głoszonych poglądów. Narzucił konieczność rewizji dotychczasowych relacji między uczestnikami rynku finansowego w skali krajowej i międzynarodowej.

Cechą wspólną dwóch największych kryzysów gospodarczych w dziejach ludzkości jest fakt, że zostały one zapoczątkowane w Stanach Zjednoczonych i jednocześnie w największym stopniu dotknęły właśnie ten kraj. Co je różni i na co zwrócono uwagę w dalszej części pracy, to przede wszystkim zachowanie regulatora rynku, a zarazem instytucji odpowiedzialnej za prowadzenie polityki pieniężnej, czyli Systemu Rezerwy Federalnej Stanów Zjednoczonych (Fed). W latach 30. ubiegłego wieku Fed wykazywał dużą bierność. Obecnie postawę Fed można przedstawić jako bardzo aktywną. Instytucja ta na bieżąco reaguje na zmieniającą się sytuację rynkową. Stosuje na szeroką skalę różne instrumentarium. $Z$ tego względu działalność Fed wyróżnia się na tle zachowań innych banków centralnych.

Przedstawienie i określenie skuteczności narzędzi wykorzystywanych przez Fed, wspierających funkcjonowanie instytucji finansowych, jak i całej gospodarki amerykańskiej w okresie globalnego kryzysu gospodarczego, to cel niniejszej pracy. Spośród szerokiego zestawu instrumentów stosowanych przez bank centralny szczególną uwagę poświęcono działaniom określonym mianem ilościowego luzowania (ang. Quantitative Easing). Analiza polityki pieniężnej realizowanej przez Fed została poprzedzona prezentacją teorii ekonomicznych poruszających kwestię skuteczności oddziaływania na gospodarkę przez narzędzia polityki pieniężnej. Ukazano także otoczenie rynkowe, problemy i oczekiwania instytucji, którym Fed musiał w pewien sposób sprostać.

\section{SKUTECZNOŚĆ POLITYKI PIENIĘŻNEJ W RÓŻNYCH NURTACH TEORII EKONOMII}

Polityka pieniężna to działalność banku centralnego polegająca na regulacji podaży pieniądza przez stosowanie wybranych instrumentów, której celem jest kształtowanie określonych parametrów makroekonomicznych (Przy- 
bylska-Kapuścińska 2008: 14). W rzeczywistości bank centralny oddziałuje głównie na bazę monetarną obiegu pieniężnego. Ilość gotówki w obiegu zależna bezpośrednio od planów emisyjnych banku centralnego jest stosunkowo niewielka w zestawieniu z drugim składnikiem bazy, czyli płynnymi rezerwami banków komercyjnych. Kreacja pieniądza depozytowego jest rezultatem oddziaływania popytu i podaży na międzybankowym rynku pieniężnym. Czynnikiem wpływającym z kolei na wspomniane wielkości są stopy procentowe ustalane przez bank centralny (Sławiński 2011: 18-19). Działania podejmowane przez bank centralny powinny zapewnić równowagę pieniężną niezbędną do osiągnięcia stabilnych warunków gospodarowania (Gruszecki 2004: 123).

Współcześnie banki centralne, realizując politykę pieniężną, najczęściej mają na uwadze utrzymanie inflacji na niskim poziomie. W przeszłości funkcje banków centralnych i istota polityki pieniężnej były inne. Poniżej zaprezentowano ewolucję teorii ekonomii dotyczących tego zakresu. Uwarunkowania i skuteczność oddziaływania polityki pieniężnej na gospodarkę w różnych nurtach teorii ekonomii zaprezentowano także $\mathrm{w}$ formie tabelarycznej.

Przez lata kruszce były utożsamiane $\mathrm{z}$ pojęciem pieniądza. Znaczenie kruszców dla bogactwa narodowego podkreślali już merkantyliści. Uważali, że wzrost ilości pieniądza ułatwia i pobudza rozwój gospodarczy. Szczytowym osiągnięciem praktyki w tym względzie było powstanie pod koniec XIX w. systemu waluty złotej zapewniającej stabilność rozwoju gospodarek oraz wymiany międzynarodowej. Ekonomiści klasyczni, a następnie neoklasyczni przyjęli natomiast założenie neutralności pieniądza w stosunku do procesów gospodarczych. Tę myśl rozwinęli reprezentanci ilościowej teorii pieniądza. Zakładali, że zmiany ilości pieniądza oddziałują jedynie na ogólny poziom cen, nie mając wpływu na zjawiska realne, takie jak wielkość dochodu narodowego czy zatrudnienie (Sobol 2008: 16-17). 


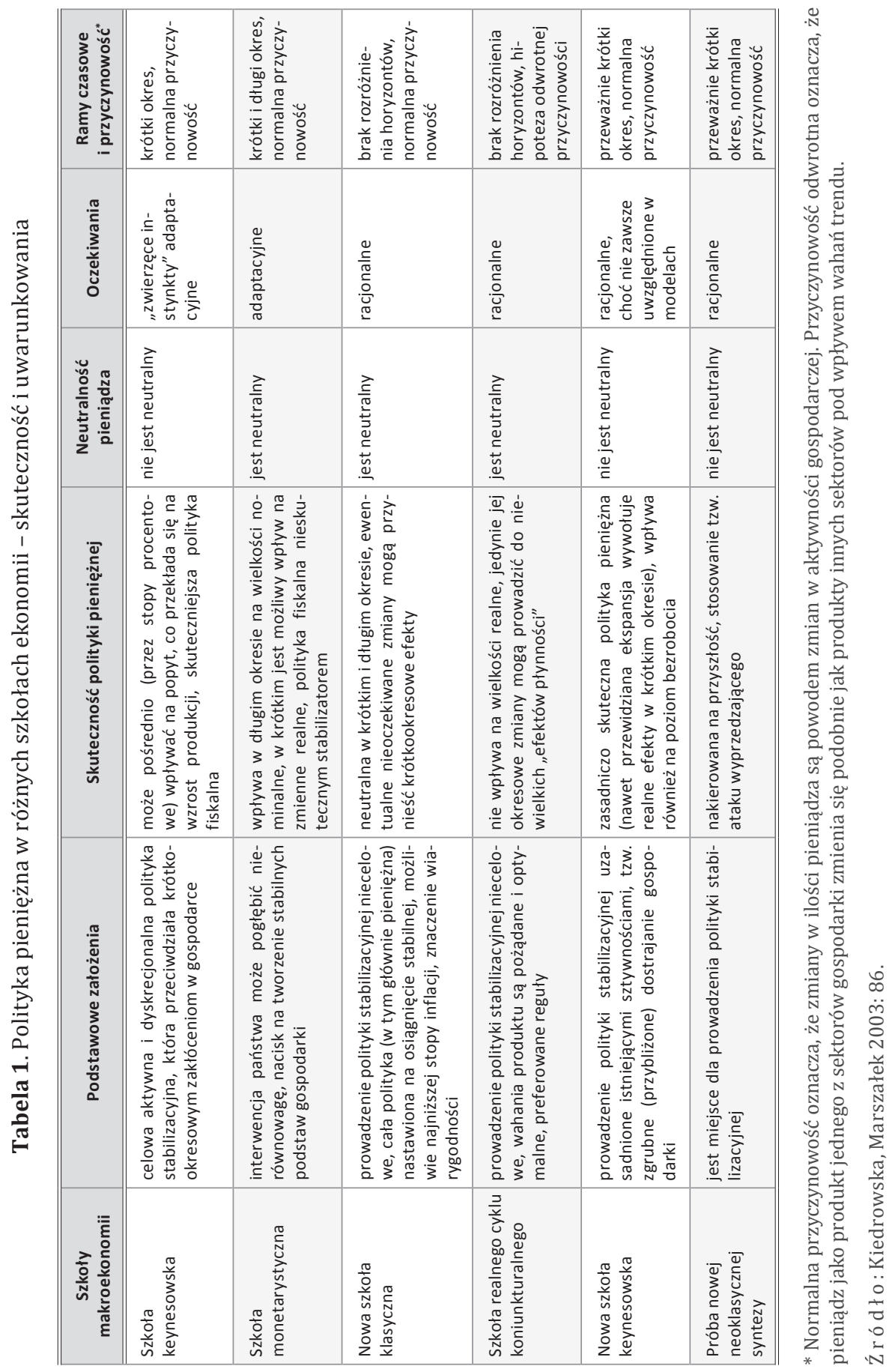


Wielki kryzys gospodarczy z lat 1929-1933 wykazał słabości dotychczasowych teorii w interpretacji zjawisk gospodarczych i prognozowaniu przyszłych zachowań rynku. Rozpoczął się kilkudziesięcioletni okres dominacji keynesizmu. Keynes uważał, że gospodarka rynkowa nie jest zdolna do samoregulacji i wymaga interwencji ze strony państwa. W dążeniu do powrotu do stanu równowagi przy pełnym zatrudnieniu miały pomagać utrzymywane na niskim poziomie stopy procentowe. W tym czasie stabilizację inflacji oraz wymiany międzynarodowej osiągnięto przez stosowanie stałych kursów walutowych będących rezultatem porozumienia z Bretton Woods. Pod koniec lat 60 . XX w., kiedy inflacja utrzymywała się jeszcze na stabilnym poziomie, M. Friedman krytycznie ocenił ekspansywną politykę pieniężną banków centralnych. Uważał on, że zwiększanie podaży pieniądza prowadzi tylko do krótkookresowych wzrostów produkcji, może natomiast skutkować trwałą inflacją (Friedman 1968). Wskazał na kontrolę podaży pieniądza jako działanie stabilizujące inflację. Jego zdaniem, podaż pieniądza powinna być dostosowana do popytu wynikającego z długoterminowego tempa rozwoju gospodarki. Zalecenia Friedmana zostały wdrożone przez banki centralne pod koniec lat 70., kiedy wiele gospodarek zmagało się ze zjawiskiem stagflacji. Kłopoty z kontrolowaniem podaży pieniądza wynikające z postępu technologicznego wkraczającego do bankowości wymusiły w latach 80. i 90. kolejne zmiany w prowadzeniu polityki pieniężnej (Mishkin 2002: 96, 682). W międzyczasie narodziła się nowa ekonomia klasyczna wprowadzająca do ekonomii hipotezę racjonalnych oczekiwań. Jej zwolennicy wskazy wali, że wpływ banku centralnego na sferę realną jest możliwy tylko w krótkim okresie, pod warunkiem zastosowania narzędzi polityki pieniężnej w sposób nieoczekiwany dla rynku. Całkowity brak wpływu polityki pieniężnej na gospodarkę prezentowali natomiast przedstawiciele teorii realnego cyklu koniunkturalnego. Obecnie dominującym nurtem myśli ekonomicznej w polityce pieniężnej jest nowa synteza neoklasyczna. W myśl tej teorii polityka pieniężna nie może przeciwdziałać powstawaniu zaburzeń w gospodarce, gdyż są one wywoływane realnymi szokami. Może natomiast w obliczu lepkości cen i płac łagodzić skutki zaburzeń i pomagać gospodarce w powrocie do stanu równowagi (Woodford 1999: 19). Z kolei rozwiązaniem często stosowanym przez współczesne banki centralne jest strategia celu inflacyjnego. $\mathrm{W}$ jej ramach bank centralny zobowiązuje się do stabilizowania inflacji na wyznaczonym poziomie (Sławiński 2006: 123-131). 


\section{CELE, STRATEGIE I NARZĘDZIA REALIZACJI POLITYKI PIENIĘŻNEJ}

Polityka fiskalna i pieniężna służą osiąganiu określonych celów gospodarczych. W historii przez dłuższy czas funkcjonował prymat polityki fiskalnej nad pieniężną. Polityka pieniężna z kolei przybierała różne formy i realizowała odmienne zadania. Były nimi wzrost zatrudnienia czy też lepsze wykorzystywanie zdolności produkcyjnych, prowadzące generalnie do silniejszego wzrostu gospodarczego. Problemy gospodarek z wysokim poziomem inflacji skierowały działania banków centralnych w stronę dbałości o zachowanie stabilnego poziomu cen utożsamianego z niskim, akceptowalnym poziomem inflacji. Kryzys finansowy ostatnich lat spowodował powrót do dyskusji o stabilności sektora finansowego traktowanej jako cel polityki pieniężnej, a jednocześnie jako swego rodzaju dobro publiczne (Szczepańska 2008). Regulacje obowiązujące w części państw dopuszczają realizowanie więcej niż jednego zadania w ramach polityki pieniężnej. Praktyka wskazuje na małą skuteczność takich rozwiązań. Często bowiem występuje konflikt między celami.

Osiągnięciu głównych celów służą strategie oparte na celach pośrednich. Wśród nich można wyodrębnić strategie tradycyjne odnoszące się do kontroli stóp procentowych, kursu walutowego lub podaży pieniądza. Strategie nowoczesne to z kolei wspomniana wcześniej strategia bezpośredniego celu inflacyjnego oraz strategie eklektyczne, odnoszące się do wiązki osiąganych celów (Pyka 2010: 41-44).

Istnieje wiele klasyfikacji i sposobów realizacji polityki pieniężnej. Z uwagi na rozważania prowadzone w dalszej części pracy należy wspomnieć o polityce ekspansywnej, wspomagającej aktywność gospodarczą, która łączy się z polityką taniego pieniądza, oraz o ich przeciwieństwie, czyli o polityce restrykcyjnej opartej na drogim pieniądzu. W realizacji założonej strategii bank centralny może opierać się na stałych regułach lub prowadzić politykę dyskrecjonalną. W pierwszym przypadku bank centralny wyznacza sobie cel i dąży do jego osiągnięcia niezależnie od rozwoju sytuacji rynkowej. Taka strategia jest stosowana przy małej wiarygodności banku lub w warunkach wysokiej inflacji. Z kolei strategia elastyczna polega na bieżącym reagowaniu za pomocą dostępnych narzędzi polityki pieniężnej na sygnały płynące z rynku (Kaźmierczak 1998: 89-90).

Bank centralny w celu realizacji przyjętej strategii stosuje odpowiednie narzędzia polityki pieniężnej. Instrumenty te można podzielić ze względu na sposób oddziały wania. Wyróżnia się wówczas instrumenty oddziaływania bezpo- 
średniego - inaczej administracyjne, pośredniego - utożsamiane z rynkowymi oraz informacyjno-perswazyjne. Mając natomiast na uwadze obszar wpływu, wyodrębnia się instrumenty kontroli ogólnej oraz te, które są wykorzystywane w kontroli selektywnej. Ze względu na typ dzielimy je na instrumenty kontroli ilościowej oraz jakościowej. Instrumentami najpowszechniej wykorzystywanymi przez banki centralne są: stopy procentowe, rezerwy obowiązkowe, operacje otwartego rynku, operacje depozytowo-kredytowe oraz pułapy kredytowe (Kaźmierczak 2008: 143-158).

\section{DZIAEANIA SYSTEMU REZERWY FEDERALNEJ W REAKCJI NA KRYZYS BANKOWY}

Kryzys to sytuacja, kiedy cała gospodarka lub główne jej elementy pozostają na poziomach znacznie poniżej optymalnych. W sektorze finansowym kryzys może przybierać formę bankowego, zadłużeniowego, rynku papierów wartościowych lub walutowego. Kryzys bankowy przejawia się problemami finansowymi znacznej części sektora, skutkującymi ograniczeniem zdolności realizacji operacji bankowych lub upadłościami banków (Iwanicz-Drozdowska 2002: 35-36). Zdaniem H. Minsky'ego u podstaw kryzysów leżą zaburzenia w makrootoczeniu skutkujące silnym wzrostem wybranych obszarów gospodarki. Ten wzrost jest finansowany przez ekspansję kredytową. W dalszej kolejności pojawiają się bąble spekulacyjne, przegrzanie koniunktury i załamanie, prowadzące nawet do paniki rynkowej (Kindleberger 1999: 22-29). Procykliczne zmiany pieniądza kredytowego, czyli wzrost ekspansji kredytowej w okresach pomyślnej koniunktury rynkowej i ograniczanie dostępu do finansowania w czasie spowolnienia gospodarczego, przyczyniają się do powstawania kryzysów, a wynikają ze zjawiska asymetrii informacji i akceleratora finansowego (Sławiński 2011: 54-55).

Dwa największe kryzysy bankowe w dziejach ludzkości, czyli z lat 1929-1933 oraz zapoczątkowany w 2007 r., w znacznej mierze dotyczyły Stanów Zjednoczonych oraz odpowiedzialnej za stabilność sektora finansowego tego kraju Systemu Rezerwy Federalnej. Doświadczenia zebrane przez Fed w okresie wielkiego kryzysu wymagają przybliżenia, gdyż w znacznej mierze rzutowały na zachowania władz tej instytucji w trakcie trwającego nadal kryzysu.

Fed, czyli bank centralny USA, został powołany w 1913 r. w reakcji na panikę bankową z 1907 r. Analizując w dalszej części pracy działania Fed, należy mieć na uwadze, że w odróżnieniu od wielu banków centralnych, podstawowymi celem tej instytucji, obok utrzymania stabilnego poziomu cen, jest dbałość 
o wzrost gospodarczy przez utrzymywanie wysokiego poziomu zatrudnienia i umiarkowanych długoterminowych stóp procentowych. W sytuacjach kryzysowych główne zadanie Fed określono jako zapewnienie bankom dostępu do płynności finansowej gwarantującej zachowanie stabilności finansowej sektora (Sławiński 2006: 139).

Wybuch wielkiego kryzysu należy wiązać z wieloma przyczynami. Przyjmuje się, że jedną z nich była błędna polityka Rezerwy Federalnej. Niewłaściwe decyzje tej instytucji oraz władz USA przyczyniły się także do pogłębienia oraz wydłużenia w czasie pozostawania amerykańskiej gospodarki w stanie kryzysu.

Dążenie do utrzymania cen na stabilnym poziomie, w sytuacji gdy gospodarka amerykańska w latach 20. ubiegłego wieku doświadczała znacznej poprawy produktywności, wymagało wzrostu ilości pieniądza w obiegu. Zwolennikami takich działań byli przedstawiciele ilościowej teorii pieniądza. Wzmożona ekspansja kredytowa finansująca rozwój gospodarki, zgodnie z szacunkami M. Friedmana i A. J. Schwarz, doprowadziła do wzrostu podaży pieniądza z 39 mld dolarów w styczniu 1921 r. do 57 mld dolarów w październiku 1929 r. Działał swego rodzaju automatyzm. Spadek ogólnego poziomu cen skutkował obniżaniem stopy dyskontowej przez bank centralny. Wzrost ilości pieniądza faktycznie spowodował wzrost produkcji oraz względną stabilizację cen dóbr konsumpcyjnych. Nie dostrzeżono jednak faktu, że nastąpiła niewłaściwa, skoncentrowana na wybranych sektorach alokacja środków powodująca nierównomierny wzrost cen. I tak, najsilniej wzrosła produkcja oraz płace w gałęziach dóbr kapitałowych, czyli w przemyśle chemicznym, hutniczym oraz stalowym (Soto 2009: 366-368). Na giełdzie natomiast nastąpił czterokrotny wzrost wartości indeksów. Można przyjąć, że w tych dwóch segmentach rynku znalazła ujście wysoka inflacja powodowana ekspansją kredytową.

Czynnikiem bezpośrednio wywołującym wybuch kryzysu mogła być podwyżka stopy dyskontowej dokonana przez Fed w 1929 r. Wzrost oprocentowania kredytów w kolejnych latach był natomiast następstwem zmniejszającej się podaży pieniądza. Monetaryści przyczynę tego zjawiska upatrywali w zbyt dużej liczbie upadłych banków. Warto w tym miejscu wspomnieć, że w latach 1930-1933 odnotowano przeszło 9 tys. tego rodzaju przypadków. Zdaniem Friedmana i innych Fed, wyznając zasadę samooczyszczania się rynku, nie realizował w sposób właściwy działań, do których został powołany. Skutkowało to przeistoczeniem się recesji w długotrwały kryzys (Iwanicz-Drozdowska 2000: 28). 
Analizując obecny kryzys bankowy, można zauważyć podobne błędy Rezerwy Federalnej do tych popełnionych w latach 20. ubiegłego wieku w okresie poprzedzającym kryzys. Zupełnie inna jest natomiast reakcja banku centralnego na sytuację braku stabilności sektora bankowego w Stanach Zjednoczonych. Wcześniej Fed wykazywał się pasywnością, obecnie stosuje niekonwencjonalne rozwiązania. Aktywne wspieranie banków przez Fed w sytuacjach kryzysowych można było w pewnym sensie przewidzieć, gdyż taki pogląd formułował B. Bernanke na wiele lat przed tym, jak został prezesem banku centralnego. Nie powinny dziwić zatem kolejne programy pomocowe adresowane do banków, jak też fakt rozpoczęcia trzeciej już rundy ilościowego luzowania polityki pieniężnej (Kozieł 2012: 12).

Początków obecnego kryzysu należy szukać w decyzjach Fed skutkujących obniżeniem podstawowej stopy dla funduszy federalnych do poziomu około 1\% obserwowanego w latach 2003 i 2004. Zamiarem podjętych działań było stymulowanie wzrostu gospodarczego, rezultatem natomiast powstanie bańki spekulacyjnej na rynku nieruchomości. Również indeksy giełdowe oraz ceny surowców zmierzały w kierunku historycznych maksimów. Źle zarządzane banki udzielały kredytów subprime, a na rynku kapitałowym dużym zainteresowaniem inwestorów cieszyły się papiery wartościowe oparte na amerykańskim rynku hipotecznym, które jak się później okazało, zawierały w sobie znaczący element ryzyka. Schładzanie koniunktury przyniosło wzrost stopy funduszy federalnych pod koniec 2006 r. do poziomu około 5,25\%. To działanie faktycznie wyzwoliło kryzys. Nastąpiło zatrzymanie, a następnie spadek cen nieruchomości. Coraz więcej kredytobiorców miało problemy z obsługą swoich zobowiązań. Pojawiły się oznaki słabnięcia koniunktury na rynku papierów wartościowych. Banki zaczęły ponosić straty nie tylko na kredytach, ale również na instrumentach finansowych powstałych w wyniku sekurytyzacji kredytów hipotecznych.

Pierwszy program wdrożony przez rezerwę federalną był reakcją na przenoszenie napięć z rynku kredytów hipotecznych na pozostałe segmenty amerykańskiego rynku finansowego. W sierpniu 2007 r. wydłużono termin oraz zmniejszono koszt pozyskania kapitału, wykorzystując w tym celu discount window będący odpowiednikiem stosowanego przez NBP kredytu lombardowego. W grudniu natomiast wprowadzono Term Auction Facility zapewniający bankom lepszy dostęp do krótkoterminowego kredytu przez rozszerzenie katalogu akceptowanych przez Fed zabezpieczeń (Monetary 2008). 
Kolejne działania były następstwem upadłości banku inwestycyjnego Bear Stearns w marcu 2008 r. Wdrożono wówczas Term Securities Lending Facility. W ramach programu, który funkcjonował do początku lutego 2010 r., banki mogły wymieniać w banku centralnym określone aktywa na papiery skarbowe. Te ostatnie zaś były akceptowane jako zabezpieczenie w pożyczkach na rynku międzybankowym. Miało to doprowadzić do ożywienia handlu na wspomnianym rynku.

Obniżenie efektywnych stóp do poziomu około $2 \%$ w połowie 2008 r. tylko na chwilę rozładowało napięcia na rynku. Upadek Lehman Brothers zachwiał rynkiem papierów dłużnych przedsiębiorstw. Pojawiły się problemy z rolowaniem zapadających papierów komercyjnych. Wsparcia tego segmentu rynku dokonano za pomocą Commercial Papers Funding Facility (Domestic 2011). Niemalże natychmiast w reakcji na upadłość tego banku zredukowano po raz kolejny koszty funduszy federalnych, tym razem do poziomu $0,1-0,2 \%$. Te działania okazały się jednak mało skuteczne, gdyż w ślad za obniżką podstawowej stopy przez Fed nie poszły obniżki stóp rynkowych. W apogeum kryzysu odchylenie 3-miesięcznej stawki LIBOR (USD) od stopy podstawowej Fed sięgało od 1 do ponad 3 punktów procentowych, gdy wcześniej oscylowało w granicach 10 punktów bazowych (Borowski 2010: 131). Rzeczywistym problemem banków w tamtym okresie był nie tyle dostęp do taniego pieniądza, ile generalnie dostęp do zewnętrznego finansowania. Wynikało to z niemalże całkowitego zamarcia transakcji na rynku międzybankowym. W obliczu ogromnych strat i bankructw wielu banków na rynku zapanował strach oraz nieufność do potencjalnych partnerów transakcji. W tej sytuacji interwencja banku centralnego skupiła się na dostarczeniu płynności bankom. Odbywało się to na różne sposoby. Często podejmowano się takich działań pierwszy raz w historii bankowości centralnej. Fed pożyczał pieniądze instytucjom finansowym wymagającym nagłej pomocy. Pożyczkami wsparto między innymi mające ogromne problemy AIG oraz sfinansowano przejęcie Bear Stearns przez J. P. Morgan. Fed wydłużał także terminy spłat zobowiązań oraz ułatwiał pozyskanie pożyczek od siebie bądź innych banków.

Względne opanowanie sytuacji w sektorze finansowym pozwoliło bankowi centralnemu skupić się na wspomaganiu gospodarki. W wyniku załamania w latach 2008-2009 gospodarka amerykańska straciła około 9 mln miejsc pracy. Konieczne więc było podjęcie nadzwyczajnych kroków w celu odbudowy zatrudnienia. Mając to na uwadze, przeprowadzono trzy rundy luzowania ilo- 
ściowego oraz operację wymiany papierów skarbowych o krótkich terminach zapadalności na dłuższe (Operation Twist).

W sytuacji, kiedy pobudzanie gospodarki zagrożonej deflacją przez obniżanie stóp procentowych stało się niemożliwe, z racji ich poziomu w pobliżu zera, podjęto działania z zakresu ilościowego luzowania polityki pieniężnej. QE różni się od typowego dodruku pieniądza, zwanego monetyzacją długu w celu przeprowadzania operacji. W przypadku dodruku jest to sfinansowanie deficytu lub długu publicznego. Celem luzowania ilościowego jest natomiast wsparcie rozwoju gospodarczego. $\mathrm{W}$ procesie tym bank centralny nabywa za dodrukowane pieniądze papiery skarbowe lub inne instrumenty finansowe. Nie zachodzi sterylizacja rynku. W rezultacie następuje wzrost wartości bilansu banku centralnego oraz zwiększa się ilość pieniądza w obiegu. Skutkiem może być obniżenie kosztu pieniądza i wzrost akcji kredytowej, ale również wzrost cen i inflacji.

Fed rozpoczął pierwszą rundę luzowania ilościowego 25 listopada $2008 \mathrm{r}$. Przeznaczył na ten cel 600 mld dolarów. Następnie, w marcu 2009 r., postanowiono rozszerzyć skalę dodruku do około 1,5 biliona dolarów. Operację zakończono w marcu 2010 r. QE2 trwało natomiast w okresie od 3 listopada $2010 \mathrm{r}$. do końca czerwca 2011 r. Skupiono z rynku instrumenty finansowe na kwotę 600 mld dolarów. W obu przypadkach Fed nabywał papiery skarbowe oraz agencyjne MBSy (Wróbel 2012: 14). Trzecia runda luzowania ilościowego została ogłoszona 13 września 2012 r. Zdecydowano przeznaczać na skup MBS około 40 mld dolarów w skali miesiąca. Nie określono przy tym horyzontu czasowego operacji. Wskazano jedynie, że będzie ona trwała tak długo, dopóki nie poprawi się sytuacja na amerykańskim rynku pracy, co oznacza spadek stopy bezrobocia poniżej 7\% (Siemionczyk 2012: 10).

Oprócz luzowania ilościowego Fed zdecydował także o przebudowaniu swojego bilansu przez sprzedaż papierów skarbowych o terminie zapadalności do trzech lat i zakup z pozyskanych w ten sposób środków papierów skarbowych o terminie wykupu między sześć a trzydzieści lat. Tego typu operacja, w odróżnieniu od QE, była już wcześniej przeprowadzana przez Fed. W pierwszym okresie od września 2011 r. do czerwca 2012 r. dokonano zamiany na kwotę 400 mld dolarów. W drugim okresie od lipca do grudnia 2012 r. planowane jest przeprowadzenie transakcji o wartości 267 mld dolarów. Zakup papierów długoterminowych ma, w zamyśle banku, prowadzić do wzrostu ich cen oraz obniżki rentowności. To z kolei ma przełożyć się na spadek kosztów długoterminowego finansowania firm i w konsekwencji pobudzić rozwój gospodarczy i wzrost zatrudnienia. 
Przedstawione powyżej programy wywarły ogromny wpływ na bilans Fed. Na początku 2007 r. bilans składał się z dwóch podstawowych pozycji: klasyczne papiery wartościowe w kwocie 772 mld dolarów oraz pożyczki dla instytucji finansowych w kwocie 88 mld dolarów. Na koniec października $2012 \mathrm{r}$. obie pozycje miały wartości odpowiednio 360 oraz 232 mld dolarów, przy czym w połowie listopada 2008 r. pożyczki przekraczały kwotę 1,5 biliona dolarów. W bilansie pojawiły się też takie pozycje, jak: zakup długoterminowych papierów skarbowych - kwota 1,28 biliona dolarów, wsparcie płynnościowe dla podstawowych rynków finansowych - kwota 2,8 mld dolarów, przy czym najwyższą wartość: 431 mld dolarów odnotowano na przełomie 2008 i 2009 r., papiery agencyjne oparte na rynku hipotecznym oraz MBSy - kwota 934 mld dolarów. Wynika z tego, że suma bilansowa Fed wzrosła z około 860 mld dolarów do 2,8 biliona dolarów (Credit 2012). Ten fakt nie jest bez znaczenia dla przyszłości rynków finansowych. Za kilka lat Fed z pewnością będzie chciał odsprzedać część posiadanych obecnie instrumentów.

\section{ZAKOŃCZENIE}

Działania podjęte przez Fed w obliczu kryzysu bankowego i gospodarczego należy uznać za odważne, ale zarazem kontrowersyjne. Ich pozytywne skutki przez powiązania własnościowe i biznesowe oraz mechanizmy psychologiczne przeniosły się z rynku amerykańskiego w inne regiony świata. Zrealizowane programy pomocowe z pewnością wyhamowały negatywne tendencje dotyczące amerykańskiego, ale i światowego sektora finansowego. Nie odnotowuje się już upadłości instytucji zagrażających stabilności sektora, spłacalność kredytów wzrosła. Stopniowo ulega odbudowie amerykański rynek pracy. Jednak nadal stopa bezrobocia wynosi około 8\%. Gospodarka wyszła z recesji, ale z drugiej strony dynamika PKB mimo tak ogromniej ilości wpompowanych pieniędzy rozwija się w tempie około $2 \%$. Dopiero od trzeciego kwartału 2011 r. zaczęła przyrastać wartość udzielonych kredytów w całym sektorze banków komercyjnych. Mając na uwadze wcześniejsze załamanie rynku kredytowego, odczytana dynamika w ujęciu rocznym rzędu 4\% nie jest wielkością satysfakcjonującą. Wspomniane kontrowersje dotyczą małej skuteczności operacji zwiększania podaży pieniądza celem wywołania ekspansji kredytowej prowadzącej do wzrostu gospodarczego. Niewielkie skutki przynoszą zapewnienia utrzymania niskiego kosztu pieniądza aż do połowy 2015 r. Przedsiębiorstwa, z obawy o stabilność warunków gospodarczych, oraz zadłużone 
do granic możliwości gospodarstwa domowe nie są zainteresowane kolejnymi kredytami. Banki natomiast znaczną część dodatkowych środków skierowały na rynek akcji oraz surowców, podnosząc wycenę wielu instrumentów do poziomów sprzed kryzysu. Fed liczył na wystąpienie efektu majątkowego zwiększającego konsumpcję, ten jednak nie jest odczuwalny. Dodruk pieniądza teoretycznie powinien spowodować osłabienie amerykańskiej waluty i wzrost konkurencyjności gospodarki, lecz tak się nie dzieje. Wzrasta natomiast presja inflacyjna. Wprawdzie inflacja w 2012 r. kształtuje się na bezpiecznym poziomie około $2 \%$, to jednak wynik ten jest w znacznej mierze rezultatem rekordowo niskiej szybkości obiegu pieniądza (M2) w systemie finansowym (Velocity 2012). Podsumowując, należy zauważyć, że dotychczasowe efekty realizowanej polityki pieniężnej w zakresie dynamizowania wzrostu gospodarczego są niewielkie, natomiast zagrożenie inflacją ogromne.

Jak wspomniano, skutki działań Fed wykroczyły poza obszar Stanów Zjednoczonych. Na świecie jest odczuwany wzrost cen surowców. Nastąpił napływ kapitałów na wybrane giełdy europejskie. Wydaje się jednak, że strumień kapitału ominął Polskę. Potwierdzają to niskie poziomy warszawskich indeksów oraz względnie słaba pozycja złotówki. Ta sytuacja może się jednak zmienić wraz z pojawieniem się pierwszych oznak ożywienia gospodarczego w Polsce, co jest prognozowane na drugą połowę $2013 \mathrm{r}$.

\section{LITERATURA}

Borowski K. (2010), Zachowanie się stóp procentowych oraz indeksów giełdowych w okresie kryzysu, [w:] Instrumenty i regulacje bankowe w czasie kryzysu, J. Nowakowski (red.), Difin, Warszawa.

Credit Easing Policy Tools (2012), Federal Reserve Bank of Cleveland, http://www.clevelandfed.org/research/data/credit_easing/index.cfm (dostęp 15.11.2012).

Domestic Open Market Operations During 2010 (2011), Federal Reserve Bank, March.

Friedman M. (1968), The Role of Monetary Policy, American Economic Review, no. 58.

Gruszecki T. (2004), Teoria pieniądza i polityka pieniężna. Rys historyczny i praktyka gospodarcza, Oficyna Ekonomiczna, Kraków.

Iwanicz-Drozdowska M. (2000), Determinanty bezpieczeństwa banków w świetle analizy wybranych kryzysów bankowych, SGH, Warszawa.

Iwanicz-Drozdowska M. (2002), Teorie kryzysów bankowych, [w:] Kryzysy bankowe. Przyczyny i rozwiqzania, M. Iwanicz-Drozdowska (red.), PWE, Warszawa.

Kaźmierczak A. (1998), Z teorii celów polityki pieniężnej, Bank i Kredyt, nr 5.

Kaźmierczak A. (2008), Polityka pieniężna w gospodarce otwartej, Wydawnictwo Naukowe PWN, Warszawa. 
Kiedrowska M., Marszałek P. (2003), Polityka pieniężna i fiskalna w teoriach makroekonomicznych, Ruch Prawniczy, Ekonomiczny i Socjologiczny, nr 1.

Kindleberger Ch. P. (1999), Szaleństwo, panika, krach. Historia kryzysów finansowych, WIG-Press, Warszawa.

Kozieł H. (2012), Gdy Rezerwa Federalna zachwiała gospodarkq USA, Parkiet, nr 208.

Mishkin F. S. (2002), Ekonomika pieniq̨dza, bankowości i rynków finansowych, PWN, Warszawa.

Monetary Policy Report to the Congress, Federal Reserve Bank, February 2008.

Przybylska-Kapuścińska W. (2008), Istota i cele polityki pieniężnej, [w:] Współczesna polityka pieniężna, W. Przybylska-Kapuścińska (red.), Difin, Warszawa.

Pyka I. (2010), Bank centralny na współczesnym rynku pieniężnym, Wydawnictwo C. H. Beck, Warszawa.

Siemionczyk G. (2012), QE już nie wprawia rynków w euforię, Parkiet, nr 247.

Sławiński A. (2006), Rynki finansowe, PWE, Warszawa.

Sławiński A. (2011), Podstawowe funkcje banków centralnych, [w:] Polityka pieniężna, A. Sławiński (red.), Wydawnictwo C. H. Beck, Warszawa.

Sobol M. (2008), Polityka pieniężna Narodowego Banku Polskiego w drodze do euro, CeDeWu.pl Platinum, Warszawa.

Soto J. H. de (2009), Pieniądz, kredyt bankowy i cykle koniunkturalne, Instytut Ludwiga von Misesa, Warszawa.

Szczepańska 0. (2008), Stabilność finansowa jako cel banku centralnego. Studium teoretyczno-porównawcze, Wydawnictwo Naukowe Scholar, Warszawa.

Velocity of M2 Money Stock (M2V) (2012), Federal Reserve Bank of St. Louis, http://research.stlouisfed.org/fred2/series/M2V?cid=32242 (dostęp 15.11.2012).

Woodford M. (1999), Revolution and Evolution in Twentieth-Century Macroeconomics, Library of Congress, Washington, June.

Wróbel Ł. (2012), Po trzecie, wyluzuj, Parkiet, nr 231. 